\title{
Muon Capture, Phase Rotation, and Cooling in Pressurized RF Cavities
}

\section{Cooperative Research and Development Agreement Final Report}

CRADA Number: FRA-2006-0002

Fermilab Technical Contact: David Neuffer

Summary Report

April 2009 


\section{NOTICE}

This report was prepared as an account of work sponsored by an agency of the United States government. Neither the United States government nor any agency thereof, nor any of their employees, makes any warranty, express or implied, or assumes any legal liability or responsibility for the accuracy, completeness, or usefulness of any information, apparatus, product, or process disclosed, or represents that its use would not infringe privately owned rights. Reference herein to any specific commercial product, process, or service by trade name, trademark, manufacturer, or otherwise does not necessarily constitute or imply its endorsement, recommendation, or favoring by the United States government or any agency thereof. The views and opinions of authors expressed herein do not necessarily state or reflect those of the United States government or any agency thereof.

Available electronically at http://www.osti.gov/bridge

Available for a processing fee to U.S. Department of Energy and its contractors, in paper, from:

U.S. Department of Energy Office of Scientific and Technical Information

P.O. Box 62

Oak Ridge, TN 37831-0062

phone: 865.576 .8401

fax: 865.576.5728

email: mailto:reports@adonis.osti.gov

Available for sale to the public, in paper, from:

U.S. Department of Commerce

National Technical Information Service

5285 Port Royal Road

Springfield, VA 22161

phone: 800.553 .6847

fax: 703.605.6900

email: orders@ntis.fedworld.gov

online ordering: http://www.ntis.gov/ordering.htm 
In accordance with Requirements set forth in Article XI.A(3) of the CRADA document, this document is the final CRADA report, including a list of Subject Inventions, to be forwarded to the Office of Science and Technical Information as part of the commitment to the public to demonstrate results of federally funded research.

CRADA number: $\quad$ FRA-2006-0002

CRADA Title: $\quad$ Muon Capture, Phase Rotation, and Cooling in Pressurized RF Cavities

Parties to the Agreement: MUONS, Inc and Fermi Research Alliance, LLC

\begin{abstract}
CRADA work:
Gas-filled rf cavities can provide high-gradient accelerating fields for muons and can be used for simultaneous acceleration and cooling of muons. In this paper we explore using these cavities in the front-end of the capture and cooling systems for neutrino factories and muon colliders. We consider using gas-filled rf cavities for the initial front-end cooling systems. We also consider using them for simultaneous phase-energy rotation and cooling in a front-end system. We also consider using lower-density rf cavities, where the gas density is primarily for rf breakdown suppression, with less cooling effect. Pressurized rf cavities enable higher gradient rf within magnetic fields than is possible with evacuated cavities, enabling more options in the front-end. The status of designs of the capture, phase rotation, and precooling systems of muon beams in pressurized cavities is described. Funded in part by SBIR grant DEFG02-05ER86252.
\end{abstract}

\title{
Summary of Research Results:
}

These initial examples demonstrate that $\mathrm{H} 2$ gas-filled rf cavities can be inserted into the phaseenergy rotation section and cooling sections and obtain muon capture and cooling as good or better than that in the optimized neutrino factory design study $2 \mathrm{~A}$ scenario ${ }^{1}$. The present examples establish that a high-performance $\mathrm{v}$-factory front end can be developed using the gasfilled cavities for simultaneous high-gradient rf and energy-loss cooling. Variations on the technique can also be explored in preparing muon beams for a $\mu^{+}-\mu^{-}$collider.

1 "Cost-effective Design for a Neutrino Factory", with J. S. Berg, S. A. Bogasz, S. Caspi, J. Cobb, R. C. Fernow, J. C. Gallardo, S. Kahn, H. Kirk, R. Palmer,K. Paul, H. Witte, M. Zisman, Phys. Rev. STAB 9,011001(2006) 
Related Reports, Publications, and Presentations:

FERMILAB-CONF-09-14-APC, April 2009, Neuffer, David et al, “Muon Capture, Phase Rotation, and Cooling in Pressurized RF Cavities"

Subject Inventions listing:

None

Report Date: April 2009

Technical Contact at Fermilab: David Neuffer

This document contains NO confidential, protectable or proprietary information. 